\title{
Improvement of XTT Assay Performance for Studies Involving Candida albicans Biofilms
}

\author{
Wander José da SILVA ${ }^{1}$ \\ Jayampath SENEVIRATNE ${ }^{2}$ \\ Nipuna PARAHITIYAWA ${ }^{2}$ \\ Edvaldo Antonio Ribeiro ROSA ${ }^{3}$ \\ Lakshman Perera SAMARANAYAKE ${ }^{2}$ \\ Altair Antoninha DEL BEL CURY ${ }^{1}$ \\ ${ }^{1}$ Department of Prosthodontics and Periodontology, Dental School of Piracicaba, \\ State University of Campinas, Piracicaba, SP, Brazil \\ ${ }^{2}$ Oral Biosciences, Faculty of Dentistry, The University of Hong Kong, Hong Kong \\ ${ }^{3}$ Department of Dentistry, Pontifical Catholic University of Paraná, Curitiba, PR, Brazil
}

\begin{abstract}
2, 3-bis (2-methoxy-4-nitro-5-sulfophenyl)-5-[(phenylamino) carbonyl]-2H-tetrazolium hydroxide (XTT) reduction assay has been used to study Candida biofilm formation. However, considering that the XTT reduction assay is dependent on cell activity, its use for evaluating mature biofilms may lead to inaccuracies since biofilm bottom cell layers tend to be relatively quiescent at later stages of biofilm formation. The aim of this study was to improve XTT reduction assay by adding glucose supplements to the standard XTT formulation. Candida albicans ATCC 90028 was used to form 24-, 48- and 72-h biofilms. The oxidative activity at 90, 180 and 270 min of incubation was evaluated. The control consisted of standard XTT formulation without glucose supplements, and was modified by the addition of 50,100 and $200 \mathrm{mM}$ of glucose. The XTT assay with $200 \mathrm{mM}$ glucose showed more accurate and consistent readings correlating with biofilm development at 24, 48 and $72 \mathrm{~h}$. Biofilm growth yield after 180 min incubation, when evaluated with the 200 $\mathrm{mM}$ glucose supplemented XTT, produced the most consistent readings on repetitive testing. It may be concluded that glucose supplementation of XTT could minimize variation and produce more accurate data for the XTT assay.
\end{abstract}

Key Words: Candida albicans, biofilm, XTT.

\section{INTRODUCTION}

Candida is a commensal fungus that inhabits half of human oral cavities. However under certain circumstances, particularly in compromised host populations such as HIV/AIDS patients and organ transplant recipients, Candida can cause opportunistic infection ranging from superficial mucous membrane infection to life-threatening systemic diseases (1).

A major virulent attribute of Candida is its ability to adhere and form surface attached microbial communities known as biofilms. Candida biofilms are especially widespread and have been observed in most medical devices, such as stents, shunts, implants, endotracheal tubes, pacemakers, and various types of catheters (2). Denture wearers can also be named as surface substrata. Biofilm development can be divided in four sequential steps: first, adhesion of microorganisms to a surface; second, discrete colony formation and organization of cells; third, secretion of extracellular polysaccharides (EPS) and maturation into a threedimensional structure; and fourth, dissemination of progeny biofilm cells (3). Therefore, it is important to evaluate the dynamic process of formation and development of Candida biofilms in order to understand the pathogenicity and treatment of this medically important fungus.

Development of biofilm on a surface can be 
better studied by quantifying the biofilm mass along different time points. Methods such as counting of colony forming units (cfu), spectrophotometric analysis, and colorimetric assays, such as 2,3-bis (2-methoxy-4nitro-5-sulfophenyl)-5-[(phenylamino) carbonyl]-2Htetrazolium hydroxide (XTT) reduction assay, have been employed to quantify the Candida biofilms. However, each method carries its own limitations and drawbacks. For example, cfu count has been shown to under-represent the cell number. In spectrophotometric analyses of cell density, all cells, both live or dead, contribute to the readings, which produces an overestimation of cell number.

XTT reduction assay has been used as a routine tool for the quantification of Candida biofilms (4-7) because it measures cell activity. The intracellular reduction of XTT releases a formozan compound that can be quantified by colorimetric estimation (4). At present, XTT reduction assay formulation contains three components namely XTT, menadione and phosphate buffer saline (PBS). XTT reduction depends on cell activity, instead of cell mass, but some authors have questioned its accuracy in biofilm quantification $(4,6)$. The development of biofilms into complex spatial structures results in uneven distribution of nutrients across their multiple layers, which can lead the cell population to a heterogeneous spectrum of metabolic activity. While nutrient-rich upper layers exhibit a relatively higher metabolic activity, nutrient-deficient basal layers have been shown to have lower metabolic activity $(3,5,8,9)$. Therefore, XTT reduction assay in mature biofilms can underestimate the cell activity of the biofilm.

Previous studies have attempted to improve the XTT assay by supplementing various ingredients to compensate for the inequalities of the metabolic activity, increasing the accuracy of biofilm quantification. Carbohydrates are the main source of energy in Candida metabolism. Glucose is easily metabolized by Candida (1) and its reasonable low cost suggests its use as a first choice. Therefore, the purpose of this study was to evaluate whether the addition of glucose supplements to the standard XTT formulation can improve the XTT reduction assay for quantification of Candida biofilms. The tested null hypothesis was that the supplementation of XTT formulation with glucose can improve the reliability and reproducibility of the test by providing the sufficient nutrient to the Candida cells across the different biofilm layers.

\section{MATERIAL AND METHODS}

\section{Candida albicans Strain}

A reference C. albicans strain (ATCC 90028) was selected for this study. The identity of the isolate was confirmed by carbohydrate assimilation tests using a commercially available API $32 \mathrm{C}$ identification system (bioMérieux, Marcy l'Etoile, France).

\section{Preparation of Candida albicans Suspension}

Prior to each experiment, the yeast strain was cultured aerobically at $37^{\circ} \mathrm{C}$ for $18 \mathrm{~h}$ on Sabouraud Dextrose Agar (SDA) and a loopful of growth was inoculated in Yeast Nitrogen Base (YNB) broth (Difco Laboratories, Detroit, MI, USA) supplemented with 50 $\mathrm{mM}$ glucose. After $18 \mathrm{~h}$ of incubation, the cells, which were in the late exponential growth phase, were harvested, washed twice with PBS (pH 7.2) and resuspended in YNB supplemented with $100 \mathrm{mM}$ glucose. Standard Candida suspensions were prepared to a concentration of $10^{7}$ cells $/ \mathrm{mL}$ by adjusting the optical density (OD) according to the McFarland standards using a Beckman Du 530 UV/visible spectrophotometer (Beckman Coulter Inc., Fullerton, CA, USA). It has been demonstrated that this cell concentration is optimal for C. albicans biofilm development (1).

\section{Biofilm Development}

C. albicans biofilm formation was performed as described by Jin et al. (1) with some modifications. Briefly, biofilms were grown in commercially available pre-sterilized, polystyrene, flat-bottomed 96-well microtiter plates (Iwaki, Tokyo, Japan). Aliquots of 100 $\mu \mathrm{L}$ of standard cell suspensions of yeasts $\left(10^{7}\right.$ cells $\left./ \mathrm{mL}\right)$ were transferred into each well and incubated for $1.5 \mathrm{~h}$ (adhesion phase) at $37^{\circ} \mathrm{C}$ at $75 \mathrm{rpm}$ in an orbital shaker (Lab-line Incubator Shaker; Elliott Bay Laboratory Services Inc., Seattle, WA, USA). After the adhesion phase, the cell suspensions were gently aspirated and each well was washed twice with PBS to remove any remaining planktonic cells, taking care not to disturb the adhered cells. In order to allow the growth of biofilm (biofilm phase), $200 \mu \mathrm{L}$ of freshly prepared YNB with 
supplemented with $100 \mathrm{mM}$ glucose was added to each well. The plates were incubated for 24,48 or $72 \mathrm{~h}$ at $37^{\circ} \mathrm{C}$ at $75 \mathrm{rpm}$ in an orbital shaker. At $24 \mathrm{~h}$ of incubation, the medium was aspirated and, biofilms were washed twice with PBS followed by addition of $200 \mu \mathrm{L}$ of fresh medium. At different time points, biofilms were quantified using the XTT reduction assay. All assays were repeated 6 times in two separate occasions.

\section{Oxidative Activity Assay}

In order to prepare the modified standard XTT formulation, anhydrous D (+) glucose (Sigma-Aldrich Corp., St Louis., MO, USA) was dissolved in sterile PBS to obtain final concentrations of 200,100 or $50 \mathrm{mM}$. PBS without glucose was used to prepare the standard XTT formulation.

XTT reduction assay was performed as previously described (1). XTT (Sigma-Aldrich Corp.) was dissolved in PBS at a final concentration of $1 \mathrm{mg} / \mathrm{mL}$. The solution was filter-sterilized and stored frozen at $-70^{\circ} \mathrm{C}$ until use. Menadione solution (0.4 mM; Sigma-Aldrich Corp.) was prepared immediately before each assay. For each assay, XTT solution was thawed on ice and mixed with menadione solution at a volume ratio of 20:1.

The biofilms were washed twice with $200 \mu \mathrm{L}$ of PBS to remove no adherent cells. Next, $158 \mu \mathrm{L}$ of PBS with or without glucose at different concentrations, 40 $\mu \mathrm{L}$ of XTT and $2 \mu \mathrm{L}$ of menadione were transferred to each well of 96-well plates. The plates were covered with aluminum foil and incubated in dark at $37^{\circ} \mathrm{C}$ for 1.5 $\mathrm{h}, 3 \mathrm{~h}$ or $4.5 \mathrm{~h}$. Thereafter, $100 \mu \mathrm{L}$ of the solution was transferred to each well of new 96-well plates. The colorimetric changes were measured at $492 \eta \mathrm{m}$ using a microtiter plate reader (Spectra-MAX 340; Molecular Devices Ltd., Sunnyvale, CA, USA).

\section{Statistical Analysis}

The statistical analysis was carried out using the SAS 9.0 software (SAS Institute Inc., Cary, NC, USA) with the significance level at $\alpha=0.05$. The dependent variables (time of incubation, glucose concentration and biofilm development) and the independent variable (oxidative activity) were analyzed statistically. The assumptions of homogeneity of variances and normal distribution of errors were tested. As the data were not normally distributed, they were transformed by exponentiation $\left(\chi^{2,4}\right)$. ANOVA was used to test the null hypothesis of no differences among the treatments. Tukey's HSD test was then used for post-ANOVA comparisons.

\section{RESULTS}

Initial analysis for the different XTT incubation times proposed in this study (90, 180 and $270 \mathrm{~min}$ ) showed that the longest incubation time had the highest OD values $(\mathrm{p}<0.001)$. However, the use of 270 -min incubation showed a high metabolic activity in 24-h biofilm, overestimating the OD value for this initial period. An incubation period of $180 \mathrm{~min}$ showed OD values consistent with increased biomass and metabolic activity. Results of 90-min incubation showed a high variance of absorbance values, indicating its lack of accuracy (Fig. 1). The incubation periods of 90 and 270 min were discontinued from further analysis due to the inaccuracy of values for reduced XTT absorbance. Thus, 180 min of XTT treatment was considered for all subsequent analyses.

Glucose concentration $(\mathrm{p}<0.001)$ and biofilm development $(p<0.001)$ were able to interfere in the oxidative activity of Candida biofilms. The 180-min readings of XTT-incubated biofilms at each glucose concentration showed a statistically significant difference from control $(\mathrm{p}<0.001)$. The addition of glucose was responsible for oxidative activity, indicating interference in the metabolic activity and resulting in

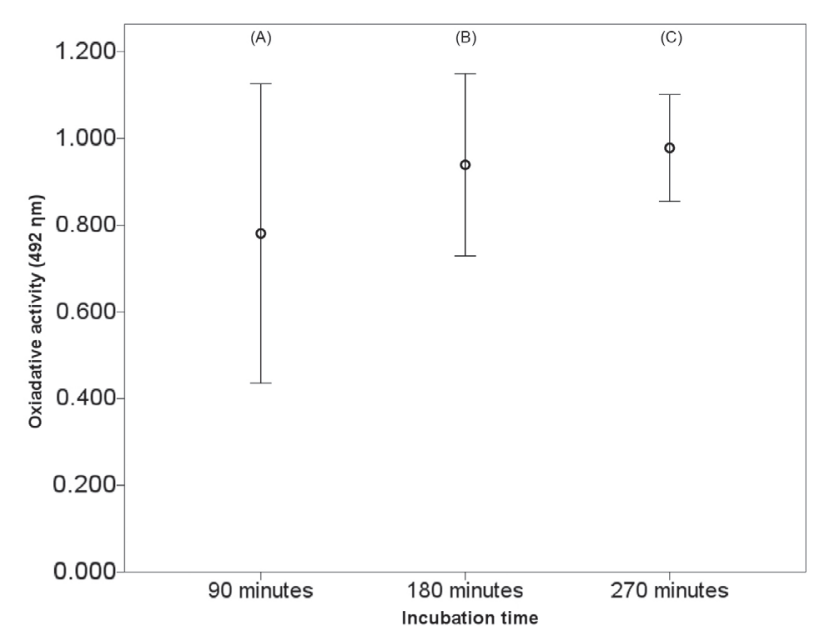

Figure 1. Biofilm oxidative activity atdifferent incubation times. 
lower coefficients of variation (control $=11.39 \% ; 50$ $\mathrm{mM}=8.81 \% ; 100 \mathrm{mM}=12.19 \%$; and $200 \mathrm{mM}=$ 6.56\%) (Fig. 2).

\section{DISCUSSION}

The present study was carried out in an attempt to improve the reliability and reproducibility of the XTT reduction assay.

C. albicans biofilm can be considered in three distinct developmental layers. The basal layer of the Candida biofilm acts as founder cells, anchoring the developing biofilm on the substrate. The middle layer is composed of hyphae and pseudohyphae, and the most superficial layer of the biofilm consists predominantly of a thicker and porous hyphal layer with abundant extracellular matrix $(3,5,8,9)$. During the growth phase, approximately $48 \mathrm{~h}$ after its formation, biofilm develops into metabolically active communities of cells that get interspersed with water channels. Biofilm structural complexity may create a gradient of environmental conditions in which the $C$. albicans cells enter distinct physiological states that differ from the planktonic counterparts (10).

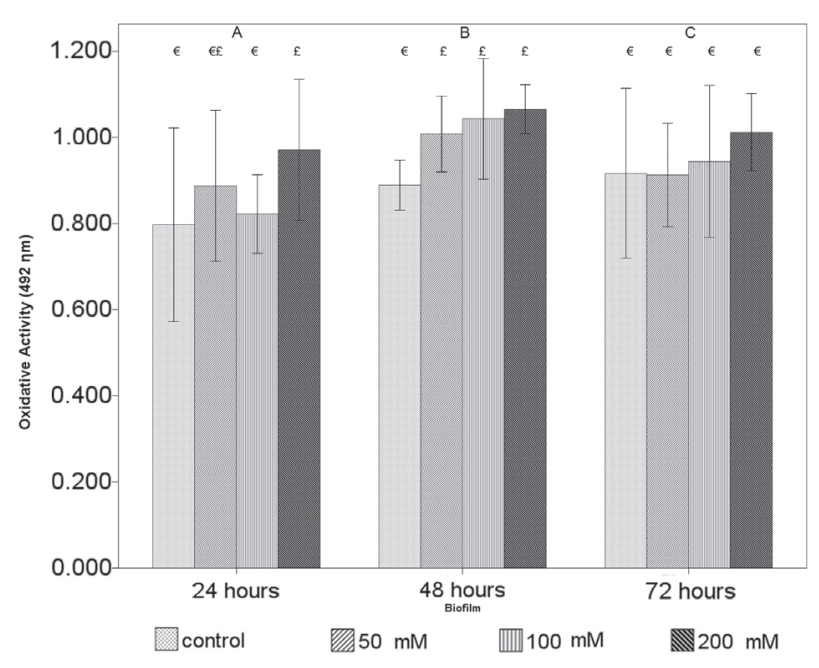

Figure 2. Oxidative activity of biofilms for different glucose concentrations. Distinct uppercase letters indicate statistically significant differences for oxidative activity among the biofilms developed at 24,48 and $72 \mathrm{~h}(\mathrm{p}<0.0001)$. Distinct symbols indicate statistically significant differences for metabolic activity and glucose concentration among the biofilms developed at 24 , 48 and $72 \mathrm{~h}(\mathrm{p}<0.0001)$.
The idea of using glucose to stimulate the mitochondrial activity of $C$. albicans biofilms derived from the hypothesis that cells in different layers undergo drastic differences concerning to oxygen and nutrient accessibility or oxidative/reductive stress. The tested hypothesis was that when not using any mitochondrial stimulus only the top layer cells, that remained exposed to outer environment, is in a position to reduce the XTT. Thus, an underestimation of the true cell content may occur. As it is well known that this yeast has a great affinity for carbohydrates (1) and that low-molar masses solutes may promptly achieve the bottom layers of biofilms $(11,12)$ flowing through the interstitial spaces (13) and diffusing from these points, it is reasonable to suppose that more cells may consume the carbohydrate and use the enzymatic mitochondrial machinery.

None of the XTT-reduction based protocols currently used for biomass evaluation, proposes the use of glucose to enhance formazan detection. Knight and Dancis (14) proposed that the reduction of some tetrazolium salts by C. albicans in unbuffered conditions may be due to reductases and they used an assay buffer containing $277 \mathrm{mM}$ glucose to assess the enzymatic activities. The results of the present study showed that the addition of glucose increased the detection of XTTreduced products, the formazans, compared to the controls without any addition. Moreover, significant differences were not observed when different glucose amounts were added, though $200 \mathrm{mM}$ glucose was proven to reduce the coefficient of variation, which what is desirable to improve the accuracy of the assay. It may be suggested that by adding glucose the examiner can detect simultaneously the cytosolic reductases (14) and the mitochondrial succinoxidase and cytochrome P450 systems, as well as flavoprotein oxidases (6).

Two questions arose during the elaboration of this idea: Is it possible that after the addition of XTT/ glucose the cells in top layers started growing faster than those in basal layers, which could lead to an erroneous result? If the cells entrapped into the extrapolymeric matrix are under absence of oxygen, how could they active the mitochondrial enzymes that work in an aerobic pathway?

The first question sounds reasonable for the cells evaluated during the adhesion phase. However, it is believed that even those washed cells when received the XTT-glucose revealing solutions required a considerable time to pass trough the "lag phase" and to enter in "log 
phase". This assumption is based on the statement of Chen et al. (15) that this "lag phase" is usually attributed to the requirement for auto-stimulatory compounds that are released into the medium as the cells proliferate, but fall below some critical concentration when the cells are diluted into fresh medium. Moreover, it is opportune to consider that the XTT-glucose solutions are not strictu sensu culture broths.

In order to answer the second question, a previous review article (16) was revisited. The relative effective diffusion coefficient $\left(D_{e} / D_{a q}\right)$ of oxygen in biofilms is near to $0.65 \times 10^{-6} \mathrm{~cm}^{2} \mathrm{~s}^{-1}$, which is much higher than the $0.30 \times 10^{-6} \mathrm{~cm}^{2} \mathrm{~s}^{-1}$ for glucose. If is assumed that glucose may achieve the bottom layers, it is reasonable to propose that the oxygen also achieves those microenvironments. In addition, both conditions of incubation (presence or absence of glucose) were conduced in opened-air systems, making it possible the diffusion of oxygen, whose diffusion coefficient in water at $35.5^{\circ} \mathrm{C}$ is $25.2 \times 10^{-6} \mathrm{~cm}^{2} \mathrm{~s}^{-1}(17)$. On the other hand, it is possible that aerobic respiration compromises the entire XTT reduction. It has been recently demonstrated (14) that the metalloenzymes superoxide dismutases (SODs), when present at $30 \mu \mathrm{g} \mathrm{mL}^{-1}$ may inhibit up to $36 \%$ of XTT reduction, although most XTT reduction is SOD-independent. Such enzymes are constitutively produced by planktonic $C$. albicans cells $(18,19)$ and at least one isozymic form has its production increased upon the entry and during the stationary phase (20). To the best of our knowledge, there are no available data concerning to the production of SODs in C. albicans cells living in biofilm.

In conclusion, XTT supplementation with 200 $\mathrm{mM}$ of glucose and a 180-min incubation time were proven a promising modification to the existing XTT reduction assay. This XTT assay can be readily used to increase the reproducibility and reliability of the results for up to 72-h-developed Candida biofilms. Since XTT reduction assay is widely used for various applications in Candida biofilms, the suggested novel XTT formulation can be useful for further studies in this research line.

\section{RESUMO}

O teste de redução do 2,3-bis (2-methoxy-4-nitro-5-sulfophenyl)5-[(phenylamino) carbonyl]-2H-tetrazolium hydroxide (XTT) tem sido utilizado para mensurar o desenvolvimento de biofilmes de Candida. Contudo, a reação de XTT é dependente da atividade celular e o seu uso para biofilmes maduros pode ser questionado, considerando que diferentes camadas celulares têm atividade metabólica diferenciadas. O objetivo deste estudo foi avaliar se a adição de glicose à formula de XTT diminuiria a variabilidade na mensuração da atividade metabólica. Biofilmes de Candida albicans ATCC 90028 com tempos de crescimento de 24, 48 e 72 $\mathrm{h}$ foram utilizados. Para avaliar o melhor tempo de incubação do XTT, este foi mantido a temperatura de $37^{\circ} \mathrm{C}$, em tempos de 90 180 e 270 min. A fórmula padrão do teste XTT (controle) foi modificada com a adição de 50, 100 e $200 \mathrm{mM}$ de glicose para os grupos experimentais. Os melhores resultados para a incubação foi observado com tempo de 180 min e para a suplementação de glicose à concentração de $200 \mathrm{mM}(\mathrm{p}<0.001)$. Concluiu-se que a incubação de 180 min utilizando a suplementação de $200 \mathrm{mM}$ de glicose apresenta resultados de atividade metabólica celular com a menor variação para o estudo de biofilmes de Candida albicans.

\section{ACKNOWLEDGEMENTS}

This study was conduced with intramural funds from the OBUHKU. Wander J. Silva (postgraduate student, PDEE/BEX 4621/ 06-9) and Edvaldo A. R. Rosa (postdoctoral fellow) were financially supported by CAPES-Brazil.

\section{REFERENCES}

1. Jin Y, Samaranayake LP, Samaranayake Y, Yip HK. Biofilm formation of Candida albicans is variably affected by saliva and dietary sugars. Arch Oral Biol 2004;49:789-798.

2. Ramage G, Martinez JP, Lopez-Ribot JL. Candida biofilms on implanted biomaterials: a clinically significant problem. Fems Yeast Research 2006;6:979-986.

3. Chandra J, Kuhn DM, Mukherjee PK, Hoyer LL, McCormick T, Ghannoum MA. Biofilm formation by the fungal pathogen Candida albicans: development, architecture, and drug resistance. J Bacteriol 2001;183:5385-5394.

4. Roehm NW, Rodgers GH, Hatfield SM, Glasebrook AL. An improved colorimetric assay for cell proliferation and viability utilizing the tetrazolium salt XTT. J Immunol Methods 1991;142:257-265.

5. Ramage G, Vandewalle K, Wickes BL, Lopez-Ribot JL. Characteristics of biofilm formation by Candida albicans. Rev Iberoam Micol 2001;18:163-170.

6. Kuhn DM, Balkis M, Chandra J, Mukherjee PK, Ghannoum MA. Uses and limitations of the XTT assay in studies of Candida growth and metabolism. J Clin Microbiol 2003;41:506-508.

7. Jahn B, Martin E, Stueben A, Bhakdi S. Susceptibility testing of Candida albicans and Aspergillus species by a simple microtiter menadione-augmented 3-(4,5-dimethyl-2thiazolyl)-2,5-diphenyl-2H-tetrazolium bromide assay. J Clin Microbiol 1995;33:661-667.

8. Baillie GS, Douglas LJ. Role of dimorphism in the development of Candida albicans biofilms. J Med Microbiol 1999;48:671-679.

9. Reese S, Guggenheim B. A novel TEM contrasting technique for extracellular polysaccharides in in vitro biofilms. Microsc Res Tech 2007;70:816-822.

10. Uppuluri P, Sarmah B, Chaffin WL. Candida albicans SNO1 and SNZ1 expressed in stationary-phase planktonic yeast cells and base of biofilm. Microbiology 2006;152:2031-2038. 
11. Thurnheer T, Gmur R, Shapiro S, Guggenheim B. Mass transport of macromolecules within an in vitro model of supragingival plaque. Appl Environ Microbiol 2003;69:17021709.

12. Zhang T, Fang HH. Effective diffusion coefficients of glucose in artificial biofilms. Environ Technol 2005;26:155-160.

13. Samaranayake YH, Ye J, Yau JY, Cheung BP, Samaranayake LP. In vitro method to study antifungal perfusion in Candida biofilms. J Clin Microbiol 2005;43:818-825.

14. Knight SA, Dancis A. Reduction of 2,3-bis(2-methoxy-4nitro-5-sulfophenyl)-2H-tetrazolium-5-carboxanilide inner salt (XTT) is dependent on CaFRE10 ferric reductase for Candida albicans grown in unbuffered media. Microbiology 2006;152:2301-2308.

15. Chen H, Fujita M, Feng Q, Clardy J, Fink GR. Tyrosol is a quorum-sensing molecule in Candida albicans. Proc Natl Acad Sci USA 2004;101:5048-5052.

16. Stewart PS. Diffusion in biofilms. J Bacteriol 2003;185:1485-
1491.

17. Han P, Bartels D. Temperature dependence of oxygen diffusion in H2O and D2O. J Phys Chem 1996;100:5597-5602.

18. Rosa EA, Pereira CV, Rosa RT, Hofling JF. Grouping oral Candida species by multilocus enzyme electrophoresis. Int $\mathrm{J}$ Syst Evol Microbiol 2000;50 Pt 3:1343-1349.

19. Rosa EA, Rosa RT, Pereira CV, Boriollo MF, Hofling JF. Analysis of parity between protein-based electrophoretic methods for the characterization of oral Candida species. Mem Inst Oswaldo Cruz 2000;95:801-806.

20. Lamarre C, LeMay JD, Deslauriers N, Bourbonnais Y. Candida albicans expresses an unusual cytoplasmic manganesecontaining superoxide dismutase (SOD3 gene product) upon the entry and during the stationary phase. J Biol Chem 2001;276:43784-43791

Accepted October 24, 2008 